\title{
DOSSIE
}

\section{Políticas Públicas em Educação Especial em Tempos de Ditadura}

\section{arquivos analíticos de políticas educativas}

Revista acadêmica, avaliada por pares, independente, de acesso aberto, e multilíngüe

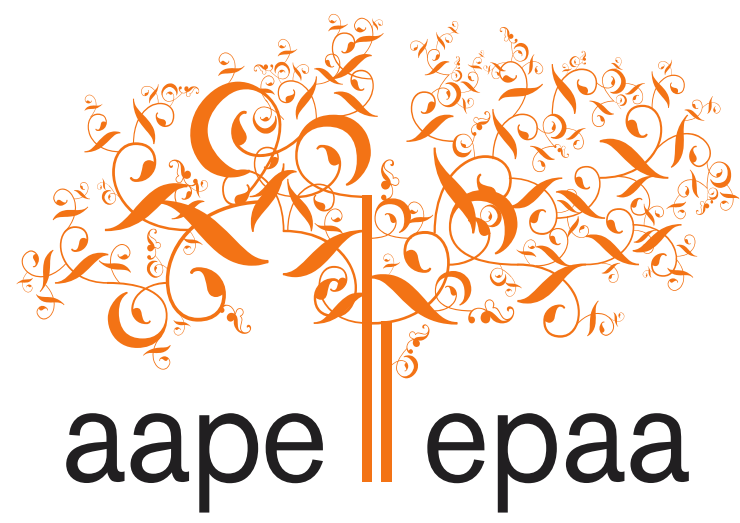

Arizona State University

\section{A Relação Público/Privado nas Políticas de Educação Especial no Período Ditatorial no Brasil (1964-1985)}

\author{
José Geraldo Silveira Bueno \\ Pontifícia Universidade Católica de São Paulo - PUC-SP \\ Brasil \\ Márcia de Souza Lehmkhul \\ Fundação Catarinense de Educação Especial - FCEE \\ Brasil \\ Ricardo Schers de Goes \\ Fundação Universidade Regional de Blumenau - FURB \\ Brasil
}

Citação: Bueno, J. G. S., Lehmkhul, M. S., \& Goes, R. S (2019). A relação público/privado nas políticas de educação especial no período ditatorial no Brasil (1964-1985). Arquivos Analíticos de Políticas Educativas, 27(62). http://dx.doi.org/10.14507/epaa.27.4481

Resumo: Este artigo tem por objetivo analisar a relação entre o público e o privado nas políticas de educação especial no Brasil durante o período da ditadura civil-militar (1964-1985), na medida em que parte do princípio de que, apesar dos avanços que as instituições privado-filantrópicas de educação especial obtiveram no período anterior (1945 a 1963), foi durante o regime ditatorial que as instituições especializadas da educação especial receberam incentivos que possibilitaram a sua 
disseminação pelo território nacional, assim como ampliaram sua influência sobre as políticas nacionais de educação especial. Por meio de análise documental, pudemos detalhar e analisar processos pouco conhecidos desta relação, envolvendo o financiamento público obtido e as influências políticas que essas entidades exerceram nesse período.

Palavras-chave: Educação Especial; Política Educacional; Relação público/privado; Filantropia; Regime Ditatorial

The public/private relationship in special education policies during the dictatorship period in Brazil (1964-1985)

Abstract: This article aims to analyze the relationship between the public and private instances in special education policies in Brazil during the period of the civil-military dictatorship (1964/1985). Despite the advances private-philanthropic institutions of special education had obtained in the previous period (1945 to 1963), it was during the dictatorship that institutions specializing in special education received incentives that allowed their dissemination throughout the Brazil. It was also during this period that they increased their influence over national policies for special education. Through document analysis, we were able to detail and analyze scarcely known processes of this relationship, involving public funding granted to these institutions and the political influence they exerted during that time.

Keywords: Special Education; Educational Policy; Public/private relationship; Philanthropy; Dictatorship

La relación público/privado en las políticas de educación especial en el período dictatorial en Brasil (1964-1985)

Resumen: Este artículo tiene por objetivo analizar la relación entre lo público y lo privado en las políticas de educación especial en Brasil durante el período de la dictadura civil-militar (1964/1985). A pesar de los avances que instituciones privadas-filantrópicas de educación especial obtuvieron en el período anterior (1945 a 1963), fue durante el régimen dictatorial que las instituciones especializadas de la educación especial recibieron incentivos que posibilitaran su diseminación por el territorio nacional y ampliaron su influencia sobre las políticas nacionales de educación especial. Por medio del análisis documental, pudimos detallar procesos poco conocidos de esta relación, involucrando el financiamiento público repartido a estas entidades y las influencias políticas por ellas ejercidas en aquel período.

Palabras-clave: Educación Especial; Política Educativa; Relación público/privado; Filantropía; Régimen Dictatorial 


\section{Introdução - A Educação Especial nos Anos Imediatamente Anteriores ao Golpe Militar}

Este trabalho tem como objetivo analisar a relação entre o público e privado nas políticas de educação especial, entre os anos de 1964 e 1985, período de ditadura civil-militar no Brasil. Parte-se do princípio de que, neste período, as instituições privado-filantrópicas ${ }^{1}$ de educação especial receberam incentivos governamentais para a expansão do atendimento às pessoas com deficiência em todo o território nacional, ampliando, desta forma, a sua influência sobre as políticas nacionais de educação especial.

Parte-se do princípio, conforme Boito (2017, p. 13), que o "Estado capitalista estabelece a distinção formal entre recursos públicos e privados, mas que na prática é apenas formal porque, ao fim e ao cabo, as

funções primordiais do Estado capitalista, garantir a dominação política da burguesia e assegurar as condições sociais e econômicas e sociais do processo de acumulação de capital, sobredeterminam todas as políticas desse Estado, inclusive a sua política social.

Nesse sentido, embora não se possa negar que parte muito importante do orçamento do Estado capitalista é aplicada em educação, saúde e lazer que são usufruídos também pela classe operária*, a posição social alcançada depende muito mais das condições sociais de origem, mas cujas

diferenças sociais são concebidas, no quadro da ideologia meritocrática, como resultado das diferenças individuais de dons e méritos de cada um. O trabalho não manual seria o apanágio daqueles cuja trajetória escolar longa e bem-sucedida comprovaria sua superioridade e méritos. (Boito 2017, p, 17)

É justamente aqui que as entidades privado-filantrópicas da educação especial cumprem seu papel de aparelhos privados de hegemonia (Gramsci, 2014), não porque pretendam ocupar totalmente a função do Estado, mas porque disseminam, num plano abstrato e genérico da "falta de dons" - a deficiência que se abateria igualmente sobre todos, independentemente de suas condições de classe - a perspectiva ideológica da filantropia como ação da sociedade em prol de qualquer manifestação de desvalia.

Para efetuar a análise aqui desenvolvida, utilizamos como fontes um conjunto de documentos que permitiram analisar como se constituiu essa relação, cujos efeitos se sentem até os dias atuais.

A recuperação, ainda que sinteticamente, da situação da educação especial no Brasil, no período imediatamente anterior ao estudado (1964 a 1985), favorecerão o entendimento da intensificação dessa relação e o papel que as instituições privado-filantrópicas assumiram em relação às políticas educacionais brasileiras, durante o regime militar.

Na primeira Lei de Diretrizes e Bases da Educação Nacional - LDBEN, promulgada no governo de João Goulart, a educação para excepcionais já era contemplada, em seu artigo 88: “A

\footnotetext{
${ }^{1}$ Apesar de reconhecermos que a repetição constante da expressão "privado-filantrópico" possa contribuir para tornar o texto monótono, a nossa posição de que a natureza e função social dessas instituições diferem das da educação regular (posição que está explicitada no corpo do texto) nos levou a decidir pelo seu uso em todo o texto.
} 
educação de excepcionais, deve, no que for possível, enquadrar-se no sistema geral de educação, a fim de integrá-los na comunidade" (Brasil, 1961)².

No entanto, sob a justificativa do atendimento aos princípios de uma educação democrática, de "liberdade e nos ideais de solidariedade humana", essa lei definia que a educação era um "direito de todos" e que poderia ser realizada "no lar e na escola", autorizando que a família educasse seus filhos em casa ou em instituições que considerassem adequadas.

A permissão para o ensino doméstico era proposta, pois o número de escolas era insuficiente para toda a população, especialmente para as crianças das camadas populares. Ou seja, o documento legitimava que a educação era um direito de todos, mas não possibilitava a igualdade de oportunidades, já que o próprio poder público não oferecia escola para todos.

Para Shiroma, Moraes e Evangelista (2007, p. 27), a promulgação da primeira Lei de Diretrizes e Bases da Educação Nacional, em 1961, regulamentou a "ajuda financeira à rede privada de forma indiscriminada", que validou os interesses da iniciativa privada e da Igreja, uma vitória das forças conservadoras brasileiras em uma conjuntura de efervescência cultural e política e de disputas ideológicas.

Para a educação da pessoa com deficiência a lógica se manteve, especialmente pela iniciativa de pais que passaram a criar escolas especiais para o atendimento de seus filhos, já que eles não eram absorvidos pelas escolas cursadas pelos filhos não deficientes ${ }^{3}$.

Assim é que a lei estabelecia, em seu artigo 88, que a "educação do excepcional" deveria ser oferecida, quando possível, no "sistema geral de educação, a fim de integrá-los na comunidade" (Brasil, 1961, Título X, Art. 88), ao mesmo tempo em que estabelecia, pelo artigo 89, que "toda iniciativa privada considerada eficiente pelos conselhos estaduais de educação, e relativa à educação de excepcionais, receberá dos poderes públicos tratamento especial mediante bolsas de estudo, empréstimos e subvenções". (Brasil, 1961).

Ou seja, mesmo antes do advento da Ditadura Civil-Militar, instaurada em 1964, a incorporação das entidades privado-filantrópicas pelas políticas de educação especial já era evidente, embora, nos anos imediatamente subsequentes à criação da primeira APAE, no Rio de Janeiro, em 1954, esse crescimento tenha sido muito lento, pois, segundo a própria associação, em 1962 existiam 16 APAES, 12 delas sediadas no Estado de São Paulo (FENAPAES, 1963).

2 Os vocábulos escritos com grafia anterior ao último acordo ortográfico da língua portuguesa foram transcritos de acordo com a ortografia atual, seguindo as orientações de Medeiros (2007): “[...]. São possíveis pequenos acertos, desde que a forma original não seja indispensável. [...] Se a transcrição tem em vista o conteúdo, não a forma, tais acertos podem ser realizados".

${ }^{3}$ Embora a criação de instituições filantrópicas tivesse se intensificado a partir da década de 1950, não se pode deixar de destacar que, na década de 1930, as Sociedades Pestalozzi foram criadas pela iniciativa de Helena Antipoff que, de uma atuação junto ao Poder Público, pela constatação da não oferta de vagas públicas para as crianças com deficiência encontrou como saída a criação de uma instituição sem fins lucrativos, Já a partir dos anos 1950, a iniciativa para a criação dessas entidades passou a ser de pais de crianças com deficiência, cuja grande expressão foram as APAEs, as quais, por meio de uma Federação Nacional, criaram um verdadeiro subsistema institucional filantrópico, assumindo gradativamente papel de destaque em toda a política nacional de educação especial. Basta ingressar nos sites dessas entidades, espalhadas por todo o país, para se constatar que a maioria esmagadora (se não a totalidade) dos beneméritos fundadores dessas associações eram, e são, pais de filhos com deficiência provenientes dos estratos sociais superiores, o que as distingue, por exemplo, dos filantropos que criam e subsidiam entidades de "auxílio à pobreza" cuja motivação é a de obter reconhecimento social pela sua "generosidade e interesse social". Para uma visão mais precisa sobre a lógica da distinção social das iniciativas de pais dos estratos superiores em relação à educação de seus filhos deficientes consultar Dallabrida (2006). 
Já em 1979, a revista Mensagem da $A P A E$ indicava que existiam mais de quinhentas Associações de Pais e Amigos dos Excepcionais - APAES, espalhadas por todo o País (FENAPAES, 1979), ou seja, a criação da Federação Nacional das APAES - FENAPAES em 1962, se efetivou quando o número de entidades era bastante reduzido, o que não confirma a afirmação de Silva (1995) de que o seu surgimento se deu em razão da quantidade de APAES distribuídas em todo o território brasileiro, ao mesmo tempo em que demonstra a sua disseminação no período aqui analisado.

O crescimento verificado acima evidencia que uma das estratégias utilizadas foi a da ampliação do número de entidades de atendimento, o que reforçaria a influência que poderiam exercer junto à sociedade e aos diferenciados níveis de ação governamental, com a Federação assumindo cada vez mais o papel de "porta-voz da área na interlocução com os órgãos públicos, [...]” (Jannuzzi e Caiado, 2013, p. 13), razão pela qual se instalou na cidade do Rio de Janeiro, a qual, embora tenha deixado de ser a capital do país, com a fundação de Brasília em 1961, ainda continha uma série de órgãos públicos federais, o que favoreceria a pretensão de se colocar como uma instituição de articulação nacional na área da educação especial ${ }^{4}$.

Por outro lado, no período anterior ao Golpe de 1964, a educação dos excepcionais, no âmbito das políticas federais, era objeto de campanhas, as quais, embora criadas por iniciativa governamentais, não integravam o organograma estrutural do Ministério da Educação ${ }^{5}$.

\section{A Relação entre o Público e o Privado no Período Ditatorial}

O primeiro ato oficial desse período, no que se refere à educação especial, foi o Decreto $n^{\circ}$ 54.188, de 24 de agosto de 1964, ou seja, menos de cinco meses após a sua instalação o governo ditatorial instituiu a "Semana Nacional da Criança Excepcional". Interessante realçar que um dos temas tratados na Assembleia Geral da FENAPAES, realizada no dia 13 de julho de 1963, no Rio de Janeiro, foi a criação da "Semana Nacional da Criança Retardada", com comemorações em todo o Brasil de 22 a 28 de agosto quando: "[...] após discussão, foi a proposta aprovada, ficando a Federação Nacional das APAES incumbida de promover a oficialização da Semana junto ao Governo Federal" (FENAPAES, 1964, p. 24).

Embora a Constituição outorgada de 1967 não tenha se referido à educação especial, a Lei no 5.692/71, que reorganizou o ensino primário e secundário instituídos pela LDB anterior, promulgada no governo de Emílio G. Médici, tendo Jarbas Passarinho como Ministro da Educação, estendeu a educação obrigatória para oito anos com a criação do Ensino de $1^{\circ} \mathrm{Grau}$, e contemplou a educação especial apenas por um único artigo:

Art. $9^{\circ}$ Os alunos que apresentem deficiências físicas ou mentais, os que se encontrem em atraso considerável quanto à idade regular de matrícula e os superdotados deverão receber tratamento especial, de acordo com as normas fixadas pelos competentes Conselhos de Educação (Brasil, 1971).

\footnotetext{
${ }^{4}$ Não se pode deixar de considerar que o primeiro órgão articulador das políticas nacionais de educação especial, o Centro Nacional de Educação Especial - CENESP, criado em 1974, instalou-se em espaço do Instituto Benjamin Constant, na Praia Vermelha, no Rio de Janeiro, cuja transferência para a nova capital federal se deu somente nos anos 1990 (Correia, 2010).

${ }^{5}$ O Decreto no 42.728, de 3 de dezembro de 1957, instituiu a Campanha para Educação do Surdo Brasileiro CESB. Seguiram-se a Campanha Nacional de Educação e Reabilitação de Deficientes da Visão (Decreto n ${ }^{\circ}$ 44.236, de $1^{\circ}$ de agosto de 1958; renomeada para Campanha Nacional de Educação de Cegos - CNEC, pelo Decreto $n^{\circ}$ 48.252, de 31 de maio de 1960) (apud Guimarães, 2017) e a Campanha Nacional de Educação e Reabilitação de Deficientes Mentais - CADEME (Decreto no 48.961, de 22 de setembro de 1960).
} 
Se, por um lado, esta lei estabeleceu de forma mais precisa o alunado da educação especial (deficiências físicas ou mentais), por outro, incluiu no âmbito de tratamento especial não somente aqueles alunos tradicionalmente integrantes no âmbito da educação especial, mas, também, os que se encontravam "em atraso considerável quanto à idade regular de matrícula", contribuindo oficialmente para a patologização do baixo rendimento escolar, ação política e educacional em evidente crescimento e muito criticada por pesquisadores como Patto (1990).

Nesse sentido, Bueno (2004) assevera que, no período ditatorial, ao lado dos deficientes, foram incluídos, no âmbito da educação especial, todos os que requeriam consideração especial no lar, na escola e na sociedade, o que permitiu a incorporação ao seu âmbito de um sem-número de alunos cuja única marca era a do baixo rendimento escolar e que atingia, fundamentalmente, os alunos oriundos das camadas populares.

Dois anos após a promulgação da Lei no 5.692/1971, exatamente em 1973, foi criado o primeiro órgão federal com a responsabilidade de organizar e normatizar a educação especial no País, o Centro Nacional de Educação Especial - CENESP, que, após diferentes denominações e diferentes inserções dentro da estrutura do Ministério da Educação - MEC, redundou na Secretaria de Educação Especial do MEC, responsável pela proposição e implementação das políticas de educação especial no Brasil:

Art. $1^{\circ}$ Fica criado no Ministério da Educação e Cultura o Centro Nacional de Educação Especial (CENESP), Órgão Central de Direção Superior, com a finalidade de promover em todo o território nacional, a expansão e melhoria do atendimento aos excepcionais.

Parágrafo único. O Cenesp gozará de autonomia administrativa e financeira, sendo as suas atividades supervisionadas pela Secretaria Geral do Ministério da Educação e Cultura.

Art. $2^{\circ} \mathrm{O}$ Cenesp atuará de forma a proporcionar oportunidades de educação, propondo e implementando estratégias decorrentes dos princípios doutrinários e políticos, que orientam a Educação Especial no período pré-escolar, nos ensinos de $1^{\circ}$ e $2^{\circ}$ graus, superior e supletivo, para os deficientes da visão, audição, mentais, físicos, educandos com problemas de conduta para os que possuam deficiências múltiplas e os superdotados, visando sua participação progressiva na comunidade. (Brasil, 1973)

Esta Secretaria, posteriormente, pelo Decreto n ${ }^{\circ}$ 7.480, de 16 de maio de 2011, foi integrada à Secretaria de Educação Continuada, Alfabetização, Diversidade e Inclusão - SECADI, como uma de suas diretorias. ${ }^{6}$

A criação do CENESP foi resultado de um conjunto de ações do governo federal decorrentes do primeiro Plano Nacional de Desenvolvimento (I PND) instituído pela Lei $\mathrm{n}^{\circ}$ 5.727, de 4 de novembro de 1971, a ser desenvolvido no período de 1972 a 1974, que, entre vários objetivos, incluiu a "política de aproveitamento dos recursos humanos do País", por meio de "programa intensivo de preparação de mão de obra, dentro da política de educação permanente" (Brasil, 1971a, p. 8).

No âmbito da educação especial, o Ministério da Educação criou um Grupo Tarefa para a elaboração de Projeto Prioritário no 35 - Educação Especial", cuja principal função foi a de "estudar

\footnotetext{
${ }^{6}$ Os decretos posteriores de reorganização do Ministério da Educação (Decretos no 7.690, de 2 de março de 2012, e n ${ }^{\circ}$ 9.005, de 14 de março de 2017) mantiveram a mesma estrutura em relação à educação especial. 7 De acordo com o documento "A Política e o Plano Setorial de Educação e Cultura", de 1973, foram criados 33 projetos prioritários da educação para compor o Plano Setorial, mas por diretriz ministerial mais três
} 
a problemática da educação especial” (Bueno, 2004, p. 122), sob a justificativa de que o "atendimento aos excepcionais é insuficiente, não atingindo, em geral, os deficientes dos vários tipos e nem os superdotados. Não apresenta padrões quantitativos e qualitativos satisfatórios” (Brasil. MEC, 1974, p. 8).

O relatório final elaborado por esse Grupo Tarefa não só indicou que o Ministério deveria promover "a expansão e melhoria do ensino ao excepcional" com um orçamento de CR \$ 8.262.500,00, como indicou a criação de um órgão responsável pela sua execução, o Centro Nacional de Educação Especial - CENESP, órgão esse efetivamente instituído pelo Decreto $n^{\circ} 72.425$, de 3 de julho de 1973 (Brasil, 1973), ficando subordinado diretamente à Secretaria Geral do MEC.

De acordo com este Decreto, o órgão deveria atuar de forma a proporcionar oportunidades de educação, propondo e implementando estratégias decorrentes dos princípios doutrinários e políticos, que orientam a Educação Especial no período pré-escolar, nos ensinos de $1^{\circ}$ e $2^{\circ}$ graus, superior e supletivo, para os deficientes da visão, audição, mentais, físicos, educandos com problemas de conduta para os que possuam deficiências múltiplas e os superdotados, visando sua participação progressiva na comunidade. (Brasil, 1973, Art. $2^{\circ}$ )

As Diretrizes Básicas para Ação do Centro Nacional de Educação Especial (Brasil/MEC/CENESP, 1974) continham como uma das suas prioridades básicas a expansão urgente do número de oportunidades de educação "para os excepcionais, quer em classes comuns, com tratamento especial; quer em classes especiais de escolas comuns; quer em instituições especializadas"» (Brasil/MEC/CENESP, 1974, p. 19).

$\mathrm{Na}$ época, para o presidente da FENAPAES, o CENESP, como órgão subordinado à Secretaria Geral do Ministério da Educação e Cultura, embora não contemplasse a proposta da FENAPAES - da criação de um "Órgão central autônomo coordenador de toda política assistencial e educacional do excepcional” (uma Fundação Nacional de Assistência ao Excepcional) - “já significava um passo a mais nas nossas conquistas" (FENAPAES, 1974, p. 1).

A primeira diretora-geral do CENESP foi a psicóloga Sarah Couto César, que trabalhava na Sociedade Pestalozzi do Brasil, no Rio de Janeiro, quando foi convidada, já no período ditatorial, pelo então Ministro da Educação Jarbas Passarinho, a dirigir a Campanha Nacional de Educação e Reabilitação de Deficientes Mentais - CADEME e que assumiu a Direção do CENESP, em 1974 (Autran e Loureiro, 2017).

Assim verifica-se que, embora a influência das entidades filantrópicas remontasse a períodos muito anteriores ao do regime militar, foi no período investigado que ela passou a ser mais incisiva, inclusive com a incorporação de seus quadros técnicos pelo novo órgão oficial de educação especial.

A incorporação de técnicos das entidades filantrópicas na esfera pública foi recorrente, já que estes eram considerados os quadros mais qualificados da área. Outro exemplo foi o da psicóloga Olívia da Silva Pereira, que atuou em diferentes espaços, como na Sociedade Pestalozzi, na Pontifícia Universidade Católica do Rio de Janeiro - PUC-RJ, compondo a equipe técnica do CENESP/MEC desde a sua criação (Autran e Loureiro, 2017), e que aparece como supervisora técnica do CENESP em publicações do MEC de 1984, o que demonstra a permanência da autora como técnica desse órgão em todo o período ditatorial.

Entre um conjunto de iniciativas, ela foi responsável pelo Projeto Especial Multinacional de Educação, que envolveu o Brasil, o Paraguai e o Uruguai, com financiamento da Organização dos

projetos foram incluídos posteriormente ao Plano, inclusive o Projeto Prioritário no 35 , que tratou da educação especial (Brasil, 1973).

${ }^{8}$ Grifo dos autores. 
Estados Americanos - OEA, tendo como um de seus principais objetivos "a difusão dos conhecimentos na área da educação especial, especialmente tendo em vista a incorporação das pessoas com deficiência "na força de trabalho"' (Pereira, 1977, p. 9).

Tanto Sarah Couto César quanto Olívia Pereira compuseram o corpo de conselheiras de redação da revista Mensagem da $A P A E$, proposta pela FENAPAES, no período estudado (FENAPAES, 1979).

Outro nome recorrente nos documentos analisados foi o da professora Rosita Edler Carvalho, que tem transitado com destaque nas esferas públicas (municipal, estadual e federal) e na esfera privada da educação especial, como também em várias universidades brasileiras, como docente e pesquisadora.

Analisando a sua trajetória profissional, verifica-se que atuou no CENESP de 1979 a 1983, como servidora pública ${ }^{9}$, na Coordenadoria Nacional para Integração da Pessoa com Deficiência CORDE, em 1991 e 1992, tendo assumido a Secretaria de Educação Especial do MEC no período de 1992 a 1994, no governo Itamar Franco.

No período anterior ao CENESP, entre 1967 e 1975, na condição de professora da APAE do Rio de Janeiro, participou de atividades promovidas pela Federação das APAES, como os Congressos Nacionais, Encontros Regionais da FENAPAES e publicações na revista Mensagem da $A P A E$.

Depois de se afastar do CENESP, voltou-se mais para a vida acadêmica, mas continuou com atuação política, assessorando a Secretaria Municipal de Educação do Rio de Janeiro (2006 a 2009) e a APAE de Vitória (2011), retornando ao âmbito federal em 2006, como membro do Conselho Consultivo da Secretaria de Educação Especial - SEESP, de onde se afastou em 2008 (Carvalho, 2017). ${ }^{10}$

A substituta de Sarah Couto César foi a neurologista Helena Bandeira de Figueiredo ${ }^{11}$, que dirigiu o CENESP de 1979 a 1982 e presidiu, em 1980, a Comissão Nacional do Ano Internacional da Pessoa Deficiente (Jannuzzi, 2006), o que, segundo Lanna Júnior (2010), causou críticas dos movimentos sociais de pessoas com deficiência, por considerar que não era a pessoa mais adequada para presidir a Comissão.

Embora a sua filiação institucional pareça indicar que estivesse ocorrendo um enfraquecimento das influências dessas entidades sobre as políticas governamentais de educação especial, isto não ocorreu na medida em que, sob sua gestão, ficou mantida a estrutura de apoio às instituições privado-filantrópicas com financiamento, orientação e supervisão e convênios.

\footnotetext{
${ }^{9}$ Em 1981, coordenou a Subcomissão na área da educação nos eventos relacionados ao Ano Internacional das Pessoas Deficientes, promovido pelo governo brasileiro, como consultora do CENESP. ${ }^{10}$ Para mais informações, acessar o Currículo Lattes de Rosita Edler Carvalho. Disponível em: $<$ http://lattes.cnpq.br/8162531397140215>. Acesso em: 2 maio 2018, ${ }^{11}$ A filiação institucional da referida neurologista é muito pouco conhecida e com parca divulgação. O que se conseguiu identificar é que, na época da sua indicação como diretora-geral ela compunha o corpo clínico do Instituto de Neurologia da Universidade do Brasil. Informações disponível em: < http://memoria.bn. br/DocReader/Hotpage/HotpageBN.aspx?bib=089842_07\&pagfis=98438\&url=http:/ / memoria.bn.br/doc reader\#>. Acesso em: 2 maio 2018.
} 


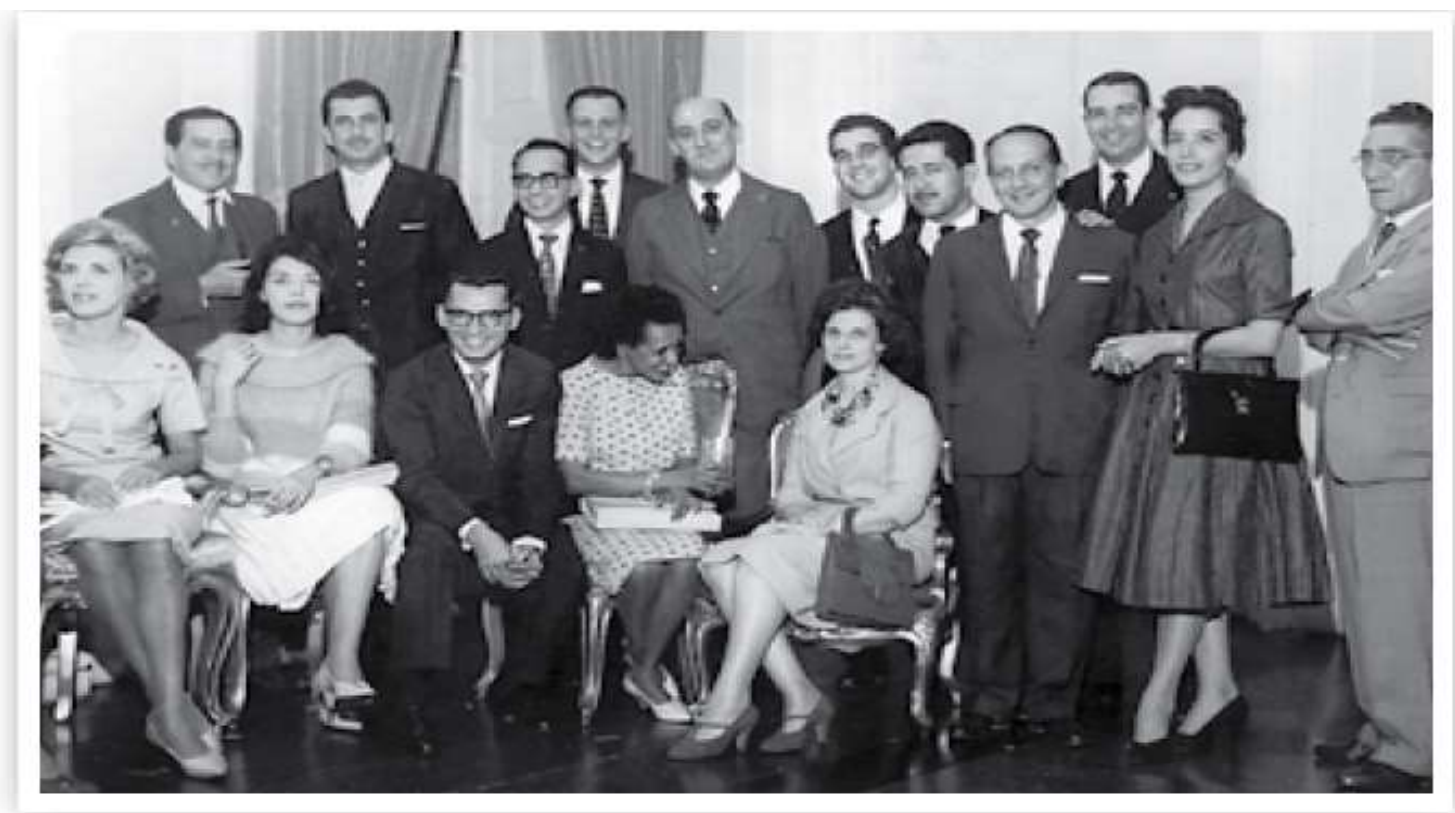

Figura 1. Corpo clínico do Instituto de Neurologia da Universidade Federal do Rio de Janeiro (na época ainda denominada como Universidade do Brasil), com a presença da Dra. Helena Bandeira de Figueiredo (sentada, $1^{\mathrm{a}}$ à esquerda). ${ }^{12}$

Fonte: Gusmão; Souza (2008)

A manutenção de estreita relação entre as entidades privado-filantrópicas e as esferas governamentais se confirma com a posse, na direção desse órgão, de Lizair de Moraes Guarino, nome bastante influente na educação especial, tendo atuado na Sociedade Pestalozzi de Niterói-RJ e assumido a presidência da Federação Nacional das Sociedades Pestalozzi - FENASP, em duas gestões, a primeira de 1970 a 1972 e a segunda de 1976 a 1983, quando se afastou para assumir a Diretoria-Geral do CENESP, onde permaneceu de 1983 a 1986, período em que coordenou o Comitê Nacional para Educação Especial, por meio do qual foi proposta a criação da Coordenadoria Nacional para Integração da Pessoa com Deficiência, subordinada ao Gabinete Civil da Presidência da República e da Secretaria de Educação Especial - SEESP, do Ministério da Educação (Lanna Júnior, 2010).

Assim como especialistas das entidades privado-filantrópicas foram sendo absorvidos pelos sistemas públicos, o que expressa o reconhecimento oficial sobre o trabalho realizado, os representantes políticos dessas instituições também foram absorvidos. Como exemplo, o médico Justino Alves Pereira, na época presidente da FENAPAES, atuou como assessor direto do Ministro da Educação e Cultura, Ney Braga, no governo do general Ernesto Geisel (FENAPAES, 1974), cujas declarações evidenciam a proximidade desses personagens com os governantes desse período:

Em 1969 e durante o nosso Congresso ${ }^{13}$ em Brasília, a criação pelo saudoso Costa e Silva, do grupo Interministerial de atualização da Legislação de Excepcional, do qual fazia parte a nossa Federação; [...]; em 1971, o honroso comparecimento ao nosso congresso no Rio de Janeiro do presidente Emílio Médici, que a par da alta deferência de sua presença e da do atual presidente Figueiredo, [...]. No interregno

\footnotetext{
12 Diferentemente das outras duas diretoras do Cenesp do período ditatorial, sobre as quais existem fotografias diversas em sites da internet, a única foto desta diretora que conseguimos selecionar encontra-se na obra citada, razão pela qual decidimos por sua inclusão neste artigo.

${ }^{13} \mathrm{O}$ autor se refere ao Congresso Nacional das APAEs que ocorreu em Brasília.
} 
destes acontecimentos marcantes e que contaram com a participação decisiva da Federação [...] (Pereira, 1979, p. 4)

Em entrevista publicada na revista Mensagem da APAE, de 1979, Sarah Couto César, a ex-diretora do CENESP, ao citar a importância e influência das APAES na política de atendimento ao excepcional, declarava que "as APAES têm influenciado no desenvolvimento dos projetos e programas governamentais", [acrescentando que] "as APAES vêm trabalhando em estreita colaboração com os órgãos federais em perfeita sintonia ", [concluindo que nos] "grupos de trabalho constituídos no MEC e em outros Ministérios é sempre solicitada a presença de uma representação das APAES. [...]. Suas conclusões e recomendações têm influenciado sem dúvida nas decisões governamentais" (FENAPAES, 1979, p. 32).

Vale a pena, ainda, destacar a influência sobre as políticas de educação especial exercida pelo acentuado caráter profissionalizante da Lei no 5.692/1971 que, segundo Lira (2010, p. 280), "foi a solução encontrada pelos ideólogos do regime para o problema da formação e qualificação de força de trabalho, [...]".

De acordo com essa perspectiva e sob a ótica da inserção social das pessoas com deficiência, o CENESP publicou o trabalho "Integração do Excepcional na Força do Trabalho", de autoria da assessora Olívia Pereira, que afirmava que a educação especial "tinha como objetivo a profissionalização da pessoa com deficiência" [...] "de contribuir, com parcela de seu trabalho, no esforço do engrandecimento nacional" [na medida em que] "poderão tornar-se úteis à sociedade" (Pereira, 1977, p. 13).

A autora justificava a importância do encaminhamento das pessoas com deficiência para o mercado de trabalho como forma de diminuição dos gastos do Estado, em razão do "quantitativo de pessoas com deficiência que recebiam subvenções (pensão) do Estado por meio do INPS, um total de 27.878 excepcionais que poderiam participar do mercado de trabalho" (Pereira, 1977, p. 156).

Os dados estatísticos do Brasil de 1987 - já no início da Nova República, mas como resultado das políticas do período anterior - ilustram a ênfase dada à profissionalização nas políticas de educação especial: 907 escolas especiais privado-filantrópicas ${ }^{14}$, com atendimento educativo em instituições especializadas de 65.911 pessoas com deficiência, sendo que, destas, 12.171 estavam participando do "atendimento em aprendizagem profissional" (Brasil/MEC/INEP, 1989, p. 79).

Mas o que pode evidenciar, de maneira mais incisiva, a relação característica da relação entre o público e o privado na educação especial refere-se às diferentes e diversificadas formas de financiamento.

Calcada na formulação da lei outorgada pelo regime ditatorial, que reorganizou o ensino de $1^{\circ}$ e $2^{\circ}$ graus, ocorreu a concessão de bolsas de estudo a alunos da rede privada, cujo modelo de financiamento para as instituições privado-filantrópicas de educação especial se diferenciou qualitativamente daquele oferecido para a rede regular.

Para esta última, a lei determinava, no parágrafo único de seu artigo 46, que "somente serão concedidas bolsas de estudo gratuitas no ensino de $1^{\circ}$ grau quando não houver vaga em estabelecimento oficial que o aluno possa frequentar com assiduidade" (Brasil, 1971), restringindo essa concessão a alunos que "demonstrarem aproveitamento e provarem falta ou insuficiência de recursos” (Brasil, 1971, Art. 46).

Se a escolarização de alunos pela rede privada regular absorvia, anteriormente, aqueles oriundos de camadas sociais superiores, a deterioração das escolas da rede pública, especialmente após a instauração da ditadura civil-militar de 1964, redundou na proliferação de escolas privadas, que absorveram alunos pertencentes a distintos estratos das camadas médias.

${ }^{14}$ Nomenclatura utilizada na época para denominar o ensino específico a pessoas com deficiência. 
$\mathrm{Na}$ educação especial, a disseminação de instituições privado-filantrópicas seguiu outra lógica, na medida em que a perspectiva que subjazia essas políticas era a do descrédito de que parcela significativa desse alunado pudesse efetivamente ser produtiva e que, portanto, deveria ser objeto da filantropia.

Assim, a distinção, no ensino regular, entre uma escolarização qualificada e com resultados mais expressivos oferecida pelas escolas privadas privilegiou os estratos sociais superiores, enquanto para a grande massa o processo de deterioração das redes públicas redundou em índices de rendimento vergonhosos, expressos pelos altos índices de repetência e evasão até meados dos anos 1990 e, a partir daí, com a implementação dos regimes de não reprovação (sistema de ciclos e progressão continuada), pela progressão escolar com níveis de aprendizagem calamitosos ${ }^{15}$.

Ou seja, enquanto para o alunado das redes privadas regulares estava garantido o direito a uma educação qualificada, o que não era de fato oferecido para o alunado das redes públicas, em razão da sua deterioração decorrente de políticas educacionais com evidente caráter de classe, para o alunado da educação especial a disseminação das instituições privado-filantrópicas expressou o não reconhecimento dos seus direitos, pois que, desvalidos, deveriam ser objeto de ajuda, de caridade da sociedade.

Assim, essa abertura para bolsas de estudo se disseminou sobre diferentes modelos, para as instituições privado-filantrópicas de educação especial, o que resultou, por exemplo, na criação de um sistema de pagamento per capita, pela Legião Brasileira de Assistência - LBA, por aluno atendido pelas instituições de educação especial.

Mas o financiamento não se restringiu somente à concessão de bolsas de estudo, mas se estendeu por muitas outras formas, envolvendo não só o governo central, como se estendendo aos governos estaduais e municipais.

No âmbito do governo federal vale a pena destacar a concessão de bolsas pelo CENESP para a formação de professores das instituições privado-filantrópicas, na medida em que as políticas de formação de pessoal especializado (professores e técnicos que já atuavam na área da educação especial) incluíam não só aqueles que atuavam nas redes públicas, mas envolviam os das instituições especiais privado-filantrópicas, como se pode constatar pelo teor do documento "Capacitação de Recursos Humanos para a Educação Especial”: “[...] torna-se indispensável o desenvolvimento das seguintes ações complementares, numa atuação integrada do CENESP, órgãos e programas do MEC e de outros Ministérios, Secretarias e Conselhos de Educação e instituições particulares" (Brasil/MEC/SG.CENESP, 1976, p. 25).

Nesse mesmo documento, em que se projetava um dos programas prioritários do CENESP para o período de 1975 a 1979, previa-se a formação dos professores e técnicos que já estavam atuando na educação especial e não de formação inicial.

Para exemplificar a expressiva participação das instituições privado-filantrópicas, basta nos reportarmos à sua meta 5, destinada à formação de 9.500 educadores, englobando os professores especializados das Secretarias de Educação, do Instituto Benjamin Constant - IBC, Instituto Nacional de Educação de Surdos - INES e instituições particulares, com uma previsão orçamentária de CR $\$ 17.713 .000,00^{16}$, valor expressivo para apenas uma das metas desse programa (Brasil/MEC/SG.CENESP, 1976).

\footnotetext{
15 Segundo Machado (2017), no segmento entre 15 e 24 anos, o analfabetismo funcional ainda é a realidade de um em cada quatro jovens. Se, desde a década de 1990, o acesso à escola tornou-se praticamente universal e a progressão escolar foi incrementada, pode-se afirmar que $25 \%$ dos jovens dessa faixa etária frequentaram, pelo menos, o ensino fundamental, sem que se apropriassem minimamente da linguagem escrita.

$16 \mathrm{O}$ que, na época, corresponderia a aproximadamente 12 mil salários mínimos que, convertidos aos valores de hoje, totalizariam cerca de 11 milhões de reais.
} 
Quando nos reportamos ao público a que se destinava tal programa, constatamos que a previsão de 5.695 professores a serem atendidos distribuía-se entre 2.275 das Secretarias de Educação e 3.420 das instituições privadas (60\% do total).

Ou seja, além de privilegiar os professores das instituições privado-filantrópicas em detrimento dos da rede pública, esse dado evidencia que a responsabilidade pelo financiamento para a formação de quadros dessas instituições era do Estado.

Este financiamento da formação de quadros das instituições privado-filantrópicas fica ainda mais evidente no caso da formação de equipes técnicas, indicada na meta 6 , em que se previa a participação de 395 técnicos das Secretarias da Educação e 1.400 técnicos das instituições privadas, também com uma dotação expressiva de cerca de 3.500 salários mínimos, o que corresponderia, nos dias atuais, a aproximadamente 3 milhões de reais.

Esse dado é ainda mais paradoxal, pois expressa uma contradição pouco explorada quanto às instituições privado-filantrópicas, tanto por seus representantes políticos quanto pelo discurso oficial: o que justificaria a necessidade de financiamento para a formação de seus quadros se essas instituições eram consideradas modelos de atendimento a serem seguidos?

Por fim, esse privilegiamento fica escancarado quando a então diretora-geral do CENESP afirmava que o MEC, por meio de um "projeto prioritário de Assistência Técnica e Financeira" às instituições particulares, vinha auxiliando o desenvolvimento de seus programas educacionais e eram as APAES “as grandes detentoras da quase totalidade dos recursos financeiros" (FENAPAES, 1979, p. 31-32).

Esses financiamentos se estendiam a outras atividades desenvolvidas, como o apoio financeiro para realização da V Olimpíada, objeto de agradecimento pelo "apoio moral e financeiro concedido pelo governo Ney Braga, através da Secretaria de Cultura e Esportes", evento que foi acompanhado pelo CENESP, ou à verba recebida de "Cr\$ $2.500 .000,00^{17}$, a qual foi distribuída entre cinquenta APAES previamente selecionadas, [...], cabendo a cada uma a quantia de Cr\$40.000,00" (FENAPAES, 1981, p. 38).

Até mesmo para a própria manutenção da Federação havia possibilidade de financiamento, em que se obteve a quantia de Cr\$500.000,00 junto ao Ministério da Saúde, para cobrir “diversas despesas administrativas, de supervisão, avaliação e materiais necessários” (FENAPAES, 1981, p. $38)$.

Enfim, as APAES são a expressão mais evidente dos múltiplos financiamentos que eram efetivados pelo governo federal às entidades filantrópicas da educação especial, aqui expressos, basicamente, por aqueles auferidos junto aos Ministérios da Saúde, da Educação, da Previdência Social e da Justiça por meio dos distintos órgãos (CENESP, Instituto Nacional de Assistência Médica e da Previdência Social - INAMPS, Legião Brasileira de Assistência - LBA, Fundação Nacional do Bem-Estar do Menor - FUNABEM, entre outros), abrangendo desde cessão de terrenos até verbas para manutenção da própria Federação.

No entanto, estas não eram as únicas fontes de financiamento, pois que cada uma das unidades ainda recebia apoio financeiro, de diversas ordens, tanto dos governos estaduais quanto dos municipais.

Ações envolvendo o governo central e estaduais eram comuns, como evidencia o depoimento do vice-presidente da APAE do Rio de Janeiro, general Floriano Moura Brasil Mendes, quando afirmava que a APAE do Rio de Janeiro havia recebido "substancial auxílio do presidente Castelo Branco, que lhe permite construir, em seu terreno, [...], uma sede condigna”, assim como

17 Pelo mesmo processo de cálculo utilizado na NR nº11, este valor corresponderia, nos dias de hoje, a R\$ 240.000,00 
agradecia ao governador do Rio de Janeiro, Faria Lima ${ }^{18}$, a doação de terreno para a construção de um Lar/Fazenda - APAE-Rio (FENAPAES, 1979, p. 14).

Outro exemplo ocorreu no Estado de Santa Catarina, em que o governador indicado pelo governo ditatorial ${ }^{19}$, Jorge Konder Bornhausen, destinou especialmente para as APAES catarinenses, por meio de projetos específicos na área da educação especial, o valor de 15 milhões de cruzeiros ${ }^{20}$, além da concessão de bolsas para o atendimento direto, que a instituição recebia por aluno atendido (FENAPAES, 1979).

Outra forma de financiamento praticada em grande monta naquele período, e que se estende até hoje, era a de cessão de professores da rede pública para o atendimento institucional, com manutenção de todos os direitos, como comprova a concessão de licença prêmio à professora efetiva da rede pública do Estado de São Paulo: "Professor I - QM -PP-II da EEPG..., D.E. de Penápolis, afastada junto a APAE de Birigui, 45 dias referente ao bloco de 7-9-71 a 6-9-76. Proc. 1454-77 DRE-A” (São Paulo, Secretaria da Educação, 1977) ${ }^{21}$, que não é exemplo único, mas se percorrermos os diários oficiais dos estados brasileiros, encontraremos um sem-número de casos semelhantes ${ }^{22}$.

No entanto, apesar do volume expressivo de apoio financeiro conseguido, tanto pela Federação quanto pelas unidades espalhadas por todo o Brasil, e dos reiterados agradecimentos de apoio aos órgãos públicos, a queixa a respeito dos montantes recebidos também era uma tônica.

Assim é que, ao lado do agradecimento pelo apoio financeiro recebido do Ministério da Previdência e Assistência Social (especialmente da Legião Brasileira de Assistência e da Fundação Nacional do Bem-Estar do Menor) que, segundo o presidente da Federação, foram "consideráveis" (FENAPAES, 1981, p. 42), no mesmo ano, o mesmo presidente lamentava a falta de apoio financeiro do Centro Nacional de Educação Especial e de outros órgãos específicos, para bolsas de estudos e merenda escolar, ainda que "sempre tenhamos enfatizado nossa reivindicação no sentido de sermos entidades educacionais e habilitadoras" (FENAPAES, 1981, p. 42).

Ou seja, de um lado, as deferências formais para aqueles que eram responsáveis pelas verbas públicas, mas, de outro, o discurso permanente de queixa sobre a sua precariedade cumpria a função de procurar, incessantemente, mais recursos públicos para sua manutenção.

Dentro desta lógica, esse foi um período em que as APAES, com protagonismo cada vez mais crescente de sua Federação, como rede privado-filantrópica da educação especial, assumiu papel preponderante, em primeiro lugar entre todas as entidades do mesmo gênero, como, por exemplo, as Sociedades Pestalozzi, que viveram um período áureo de crescimento a partir das iniciativas de Helena Antipoff, nas décadas anteriores, superadas amplamente pela atuação política

\footnotetext{
18 Floriano Peixoto Faria Lima foi escolhido por Geisel, em 1974, para assumir o governo do Estado do Rio de Janeiro, quando da fusão deste com o Estado da Guanabara, momento em que se filiou à Aliança Renovadora Nacional - ARENA. Informações disponíveis em: <http://www.jb.com.br/rio/noticias/ 2011/07/10/ morre-aos-93-anos-o-ex-governador-do-rio-faria-lima/>. Acesso em: 19 julho 2016.

${ }^{19}$ No ano de 1965, o então presidente Castello Branco promulgou o Ato Institucional no 2, AI-2, extinguindo os partidos políticos e instituindo a eleição indireta de presidentes, governadores e prefeitos de cidades consideradas de segurança nacional, sistema que permaneceu até 1980 (Lira, 2010).

${ }^{20}$ O salário mínimo médio de 1979 girava em torno de Cr $\$ 2.500,00$ (dois mil e quinhentos cruzeiros), o que significa que somente as APAEs de Santa Catarina receberam subvenção estadual no valor de 6 mil salários mínimos. Nos valores de hoje, essa subvenção corresponderia a R \$ 5.622.000 (R \$ 937,00 - valor do salário mínimo atual X 6.000),

${ }^{21}$ Tanto o nome da professora quanto da escola foram omitidos para preservar as suas identidades, já que não ocasionam qualquer tipo de limitação aos argumentos aqui utilizados.

${ }^{22}$ Maiores informações a respeito desse tipo de financiamento consultar Lehmkuhl (2018).
} 
das APAES, especialmente de sua Federação, junto aos diferentes níveis dos governos, como de divulgação junto à sociedade.

Este crescimento exponencial das instituições privado-filantrópicas, capitaneado sem dúvida pelas APAES, pode ser observado pelo crescimento do número de instituições especializadas que passou de 494, em 1981, para 904, em 1987, ou seja, um incremento de 83\% em seis anos (Bueno, 2004).

Mas a expressão mais importante refere-se às matrículas de alunos da educação especial nesse período:

Tabela 1 Matrículas na educação especial por dependência administrativa (1974-1987)

\begin{tabular}{ccccc}
\hline & Públicas & No Índice $^{\text {Privado- }}$ & N $^{\circ}$ Índice \\
\hline 1974 & 56.065 & 1,00 & 40.348 & 1,00 \\
1981 & 60.836 & 1,08 & 43.432 & 1,07 \\
1987 & 88.521 & 1,57 & 70.804 & 1,75 \\
\hline
\end{tabular}

Fonte: Bueno (2004).

Os dados da Tabela 1 evidenciam que, se no primeiro período o crescimento proporcional das matrículas entre as diferentes instâncias do poder público (federal, estadual e municipal) e as instituições especiais foi praticamente idêntico, entre 1982 e 1987 as matrículas nessas últimas apresentaram incremento expressivamente superior que as das redes públicas de ensino ${ }^{23}$.

A quantidade de informações sobre as implicações das políticas de educação especial que redundaram sistematicamente no apoio financeiro a entidades que, mesmo que cumprissem de forma qualificada a sua função social (o que nem sempre foi verdade), contribuíram e continuam a contribuir para a manutenção da omissão do Estado em relação ao direito à educação da população atendida pelos sistemas de educação especial, poderiam ser muito mais ampliadas, mas o que aqui se apresentou nos pareceu suficiente para sustentar essa tese.

\section{Considerações Finais}

Sendo assim, embora na escola regular a educação seja tratada como direito público subjetivo, trazendo como consequência legal que a matrícula no sistema privado não pode ser resultado de falta de oferta de vaga pelo Estado, na educação especial a situação é substantivamente alterada, na medida em que as entidades sem fins lucrativos, que funcionam sob a égide da filantropia, têm papel preponderante na oferta de vagas para alunos com necessidades educacionais especiais.

A educação, reconhecida como um dos direitos fundamentais do homem e presente na legislação brasileira, consiste na obrigatoriedade e na gratuidade da educação, que pode ser oferecida de diversas maneiras a depender da legislação de cada país, mas, em geral, como um direito

${ }^{23}$ Cabe lembrar que, naquele período, muito mais do que hoje, como grande parte das instituições especializadas não estava regulamentada como escolares junto aos órgãos oficiais competentes, certamente o número de matrículas deveria ser superior ao registrado pelo Ministério da Educação, o que não ocorria com as estatísticas das matrículas da rede pública, cuja probabilidade de estarem mais próximas da realidade é evidente. 
fundamental do cidadão, em nosso País é explicitada desde a Constituição Federal de 1934: a escola elementar é compulsória e gratuita.

No entanto, com a criação de um órgão federal, bem como com a divulgação de que a educação especial era uma das prioridades, no período da ditadura civil-militar, os documentos analisados indicavam que

cerca de $12 \%$ de excepcionais na população escolar e sendo a população global brasileira dos 7 aos 14 anos de 19,39 milhões verifica-se que somente nessa faixa etária é provável que existam 2,66 milhões de educandos demandando educação especial. Está sendo prestado atendimento especializado apenas a 50.274 alunos. Por outro lado, um número elevado de excepcionais já se encontra frequentando escolas comuns, não estando estes alunos identificados e, por conseguinte, não recebendo tratamento especial (Brasil/MEC/CENESP, 1974, p. 18)

Esses dados evidenciam que, embora não se possa deixar de reconhecer que coube ao regime ditatorial a primeira iniciativa do executivo federal de criação de órgão específico para a educação especial, os dados da Tabela 1, referentes ao período, de crescimento exponencial das matrículas (57\% nas redes públicas e 75\% nas instituições privado-filantrópicas, entre 1974 e 1987), corresponderam à absorção de $5,5 \%$ da população que deveria ser absorvida pela educação especial nesse último ano.

Em suma, apesar da divulgação de metas ambiciosas referentes ao acesso à escolarização da população abrangida pela educação especial, os números indicavam, no que se referia aos alunos com necessidades educacionais especiais, que elas estavam muito distantes de serem alcançadas.

O que merece ser destacado nessa relação entre os poderes públicos e as entidades privadofilantrópicas da educação especial é que ela tem uma natureza completamente diferente da relação público/privado na educação geral.

Nesta última, o Estado foi efetivamente assumindo a primazia da oferta de educação básica, substituindo, por exemplo, as antigas iniciativas de ordens religiosas voltadas à educação de crianças oriundas das camadas populares, que se mantinham, inclusive, com subsídios estatais, fazendo com que as escolas privadas se direcionassem, fundamentalmente, para as camadas sociais superiores.

Essa situação, na verdade, espelha o elitismo da escola básica brasileira, que oferece à população em geral uma educação pública marcada pela baixa qualidade do ensino e de uma educação privada de melhor qualidade ${ }^{24}$.

No caso da educação especial, essa não é a marca distintiva porque a grande massa da população atendida por ela, no entanto, gira em torno de uma escolarização pública de baixa qualidade, cujos resultados são muito ruins, e das instituições privado-filantrópicas, de caráter assistencialista, que, em regra, também oferecem atendimento de qualidade questionável.

A exceção fica por conta de uma reduzidíssima parcela da população, com altíssimo poder aquisitivo, que permite a inserção de seus filhos em escolas privadas regulares de alto custo, com apoio intensivo, tanto do ponto de vista da saúde quanto da educação, o que garante uma escolarização de qualidade, dentro das limitações de cada tipo de deficiência.

No entanto, se é verdade que a ampliação do acesso ao ensino regular é um fato inquestionável, comprovado pelos dados estatísticos atuais ${ }^{25}$, a influência das instituições privado-

\footnotetext{
${ }^{24}$ Se no período dos governos Lula e Dilma a melhoria dos processos de escolarização dos alunos oriundos das camadas populares constituiu uma de suas metas (mesmo que com graves problemas), as ações do governo ilegítimo atual, resultante do golpe político parlamentar-jurídico-midiático, evidenciam o movimento retrógrado que as forças conservadoras executam de barateamento e de deterioração, assim como de ataques a toda e qualquer manifestação em prol da escola pública.
} 
filantrópicas não só se manteve como foi ampliada, na medida em que estas foram incorporadas como agentes do chamado Atendimento Educacional Especializado, que visa oferecer o apoio para a inclusão nas classes regulares de alunos com deficiência, transtornos globais de desenvolvimento e superdotados/com altas habilidades.

Essa nova forma de incorporação não pode ser considerada apenas como continuidade da influência dessas entidades sobre as políticas públicas, pois, mais que isso, evidencia uma distinção qualitativa importante nessa influência e um paradoxo do ponto de vista técnico-científico:

- no que se refere à influência, essas entidades agora não só têm seus representantes ocupando cargos nos órgãos públicos e recebem financiamento e apoio das diversas instâncias do poder público, como foram absorvidas pelo Estado, ou seja, agora fazem parte efetiva dos serviços oferecidos pelo poder público;

- quanto ao paradoxo técnico-científico, verifica-se que as instituições especializadas, que desde sua origem primaram por processos de escolarização através de atendimento segregado, passam, agora, a oferecer serviços de apoio para a inclusão escolar de alunos com necessidades educacionais especiais; em palavras mais duras, a responsabilidade pelo sucesso dessa política recai sobre entidades que nunca promoveram a inclusão escolar.

Na verdade, a ambiguidade entre a obrigação do poder público de escolarização de alunos com necessidades educacionais especiais e a outorga de parte dessa obrigação a entidades privadofilantrópicas evidencia a perspectiva de que essa população pouco pode oferecer para o desenvolvimento nacional e indica o lugar que devem ocupar: o da benemerência por parte dos membros e instituições produtivos.

Nesse sentido, cabe concluir este artigo nos apropriando das contribuições de Soares (1999, p. 106), quando afirma que não "há luta pela caridade: esta é obtida através de apelo, em que se ressalta o infortúnio de quem recebe, por um lado e, por outro, a existência privilegiada do doador".

Ou seja, para ela, com base em Ozouf (1989, apud Soares, 1999), as políticas de educação especial estão calcadas no primado liberal da fraternidade, enquanto para a população em geral nos de liberdade e igualdade.

Ou melhor, enquanto para a população em geral a educação é regida pelos princípios dos direitos civis, os da educação especial se situam em torno de uma máxima moral, que pode ser contemplada ou não, já que não se é obrigado a ser fraterno com qualquer um.

Assim, se é verdade que um período político ditatorial e conservador pôde oferecer meios para que o interesse privado se impusesse em detrimento ao direito da maioria e de incentivo ao âmbito do assistencialismo, o fato de ter sido superado não significa que tenhamos conseguido reverter tanto o privilegiamento das elites quanto o assistencialismo dos "infortunados".

Os últimos rumos das atuais políticas nacionais colocam em risco os avanços que tinham sido obtidos no campo educacional após a queda do regime de 1964, especialmente por meio de pressões dos movimentos organizados em prol da melhoria da qualidade e da democratização da educação pública.

A sua superação exige luta constante e contínua por todos aqueles que almejam uma sociedade mais justa e igualitária para todos, inclusive para os alunos da educação especial.

\footnotetext{
25 Segundo dados oficiais do Ministério da Educação, em 2016 as matrículas do alunado da educação especial na educação básica estavam assim distribuídas: 796.486 em classes comuns do ensino regular e $174.886 \mathrm{em}$ classes ou escolas exclusivamente especializadas ou em classes especiais do ensino regular (Brasil/MEC/INEP, 2016).
} 


\section{Referências}

Autran, I. M. F. P., \& Loureiro, V. R. (2017). Memória da educação especial na PUC-Rio: Resgatando a história. Rio de Janeiro, PUC-Rio. Acessado em: https://www.maxwell.vrac.pucrio.br/15524/15524.PDF.

Boito Jr., A. (2017). A corrupção como ideologia. Crítica Marxista, Campinas, 44, 9- 19.

Brasil. (1960). Decreto n 48.961, de 22 de setembro de 1960, que institui a Campanha de Educação e Reabilitação de Deficientes Mentais. Brasília: Câmara dos Deputados. Acessado em: http://www2.camara.leg.br/legin/fed/decret/1960-1969/decreto-48961-22-setembro-1960388634-publicacaooriginal-1-pe.html.

Brasil. (1961). Lei n 4.024, de 20 de dezembro de 1961, fixa as Diretrizes e Bases da Educação Nacional. Brasília: Casa Civil. Acessado em: http://www. planalto .gov.br/ ccivil03/leis/L4024.htm.

Brasil. (1971a). I Plano Nacional do Desenvolvimento (PND) - 1972-1974. Brasília.

Brasil. (1964). Decreto $n^{\circ} 54.188$, de 24 de agosto de 1964, que institui a Semana Nacional da Criança Excepcional. Brasilia: Câmara dos Deputados. Acessado em: http:

//www2.camara.leg.br/legin/fed/decret/1960-1969/decreto-54188-24-agosto-1964394252-publicacaooriginal-1-pe.html.

Brasil. (1965). Decreto $n^{\circ} 55.551$, de 12 de janeiro de 1965, que regulamenta a Lei $n^{\circ} 4.440$, de 27 de outubro de 1964, que institui o Salário-Educação, e dá outras providências. Brasília: Câmara dos Deputados. Acesssado em: http://www2.camara.leg.br/legin/fed/decret/1960-1969/decreto-55551-12janeiro -1965-395895-publicacaooriginal-1-pe.html.

Brasil. (1971). Lei ñ 5.692, de 11 de agosto de 1971, fixa diretrizes e bases para o ensino de $1^{\circ}$ e $2^{\circ}$ graus. Brasília: Casa Civil. Acessado em: http://www.planalto.gov.br/ ccivil_03/leis/15692.htm.

Brasil. (1973). Decreto $n^{\circ} 72.425$, de 3 de julho de 1973, que cria o Centro Nacional de Educação Especial (CENESP). Brasília: Câmara dos Deputados. Acessado em: http://www2.camara.leg.br/legin/fed/decret/1970-1979/decreto-72425-3-julho-1973420888-publicacaooriginal-1-pe.html.

Brasil. (1986). Decreto n 93.613, de 21 de novembro de 1986, que extingue órgãos do Ministério da Educação e dá outras providências. Acessado em: http://www2.camara.leg.br/legin/fed/decret/1980-1987/decreto-93613-21-novembro1986-444224-publicacaooriginal-1-pe.html.

Brasil. (2011). Decreto $n^{\circ} 7.480$, de 16 de maio de 2011, que aprova a Estrutura Regimental e o Quadro Demonstrativo dos Cargos em Comissão do Grupo Direção e Assessoramento Superiores DAS e das Funções Gratificadas do Ministério da Educação e dispõe do remanejamento de cargos em comissão. Acessado em: http://www. planalto.gov.br/ccivil_03/_ato20112014/2011/decreto/d7480.htm.

Brasil. (2012). Decreto $n^{\circ}$ 7.690, de 2 de março de 2012, que aprova a Estrutura Regimental e o Quadro Demonstrativo dos Cargos em Comissão e das Funções Gratificadas do Ministério da Educação. Acessado em: http://www.planalto.gov.br/ccivil03/ato20112014/2012/decreto/D7690.htmimpressao.ht $\mathrm{m}$.

Brasil. (2017). Decreto $n^{\circ}$ 9.005, de 14 de março de 2017, que aprova a Estrutura Regimental e o Quadro Demonstrativo dos Cargos em Comissão e das Funções de Confiança do Ministério da Educação, remaneja cargos em comissão e substitui cargos em comissão do Grupo-Direção e Assessoramento Superiores - DAS por Funções Comissionadas do Poder Executivo FCPE. Acessado em: http:/ /www.planalto.gov.br/ccivil_03/_ ato2015-2018/2017/ decreto/D9005.htm. 
Brasil. Ministério da Educação (MEC/SEG). (1973). A Política e o Plano Setorial de Educação e Cultura. Brasília: SEG.

Brasil. Ministério da Educação (MEC/CENESP). (1974). Diretriz̧es Básicas para Ação do Centro Nacional de Educação Especial. Brasília: MEC/CENESP.

Brasil. Ministério da Educação (MEC/SG.CENESP). (1975). Educação Especial: Dados estatísticos 1974. Brasília: MEC.

Brasil. Ministério da Educação (MEC/SG.CENESP). (1976). Capacitação de Recursos Humanos para a Educação Especial. Brasília: MEC.

Brasil. Ministério da Educação (MEC/INEP). (1989). Sinopse Estatística da Educação Especial: volume II - Instituições Especializadas. Brasília: MEC/SG/SEPLAN/SEEC.

Brasil. Ministério da Educação (MEC/INEP). (2017). Sinopse estatística da educação básica. Acessado em: portal.inep.gov.br/web/guest/sinopses-estatisticas-da-educacao-basica.

Bueno, J. G. S. (2004). Educação especial brasileira: Integração/segregação do aluno diferente. São Paulo, SP: EDUC.

Carvalho, R. E de. (2017). Curriculo lattes. Acessado em: http://lattes.cnpq.br/8162531397140215.

Correia, M. A. M. (2010). Educação especial - Vol. 1. Rio de Janeiro, RJ: Fundação CECIERJ.

Dallabrida, A. (2006). As famílias com filhos deficientes e a escolha da escola: o caso do Colégio Coração de Jesus (Tese de Doutorado). Pontifícia Universidade Católica, São Paulo.

Federação Nacional das APAES (FENAPAES). (1963, jan). Mensagem da APAE, 1(1)

Federação Nacional das APAES (FENAPAES). (1964, jan.-mar.). Mensagem da APAE, 2(1).

Federação Nacional das APAES (FENAPAES). (1965, jan.-dez.). Mensagem da APAE, 3(1-4).

Federação Nacional das APAES (FENAPAES). (1968, abr.-jun.) Mensagem da APAE, 5(2).

Federação Nacional das APAES (FENAPAES). (1974, nov.) Mensagem da APAE, 1(1).

Federação Nacional das APAES (FENAPAES). (1979, nov.) Mensagem da APAE, 6(16).

Federação Nacional das APAES (FENAPAES). (1979b, nov.). Mensagem da APAE, 6(17).

Federação Nacional das APAES (FENAPAES). (1981, jul.-set.). Mensagem da APAE, 8(25)

Guimarães, A. S. (2017). Educação especial: Do "atendimento educacional especializado aos portadores de deficiência" à educação dos portadores de necessidades especiais. In: Senado federal. Instituto legislativo brasileiro. A Constituição de 1988: O Brasil 20 Anos Depois - Os Cidadãos na Carta Cidadã (vol. V). Brasília, Senado Federal. Acessado em: https://www12.senado. leg.br/publicacoes/estudos-legislativos/tipos-de-estudos/outraspublicacoes/vo lume-vconstituicao-de-1988-o-brasil-20-anos-depois.-os-cidadaos-na-carta-cida da/educacao-ecultura-educacao-especial-do-atendimento-educacional-especiali zado-aos-portadores-dedeficiencia-a-educacao-dos-portadores-de-necessidades-especiais.

Gramsci, A. (2014). Cadernos do cárcere. V. 3 Maquiavel: Notas sobre o Estado e a política. Rio de Janeiro, Civilização Brasileira, pp. 2 a 14.

Gusmão, S. S., \& Souza, J. G. de. (2008). História da neurocirurgia no Brasil. São Paulo, Sociedade Brasileira de Neurocirurgia.

Jannuzzi, G. (2006). A educação do Deficiente no Brasil: Dos primórdios ao início do século XXI. Campinas, SP: Autores Associados.

Jannuzzi, G., \& Caiado, K. R. M. (2013). APAE: 1954 a 2011 - algumas reflexões. Campinas, SP: Autores Associados.

Lanna Junior, M. C. M. (Comp.). (2010). História do movimento político das pessoas com deficiência no Brasil. Brasília: Secretaria de Direitos Humanos, Secretaria Nacional de Promoção dos Direitos da Pessoa com Deficiência.

Lehmkuhl, M. de S. (2018). A reconstituição da Federação Nacional das APAES (FENAPAES) no estabelecimento da relação entre público e privado nas políticas de educaşão especial (1974/2010) (Tese de Doutorado). Pontifícia Universidade Católica, São Paulo. 
Lira, A. T. do N. (2010). A legislação de educação no Brasil durante a ditadura militar (1964-1985): Um espaço de disputas (Tese de Doutorado). Universidade Federal Fluminense, Niterói.

Machado, S. (2018). Os parâmetros do analfabetismo funcional. Acessado em: http://www.multirio.rj.gov.br/index.php/leia/reportagensartigos/reportagens/12236-ospar $\% \mathrm{C} 3 \% \mathrm{~A} 2 \mathrm{metros}-\mathrm{do}$-analfabetismo-funcional.

Medeiros, N. L. (2007). Fórum de normalização, padronização, estilo e revisão do texto científico: Perguntas, respostas, discussões e questionamentos sobre $A B N T$, teses, dissertações, monografias, livros, artigos cientificos. Acessado em: http://www.editoraforum.com.br/sist/diabiblioteca /ebookbibliotecario1.pdf.

Ozouf, M. (1989). Fraternidade. In: F. Furet \& M. Ozouf, Dicionário crítico da Revolução Francesa. Rio de Janeiro, RJ: Nova Fronteira.

Patto, M. H. S. (1990). A produção do fracasso escolar. Histórias de submissão e rebeldia. São Paulo, Casa do Psicólogo.

Pereira, J. A. (1979). Dimensão histórica do movimento apaeano. Mensagem da APAE, 6(16).

Pereira, O. S. (1977). Integração do excepcional na força de trabalho. Brasília: MEC. Departamento de Documentação e Divulgação.

São Paulo. Secretaria da Educação. (1977, 17 de Agosto). Diário Oficial do Estado. Acessado em: https://www. imprensaoficial.com.br/.

Shiroma, E. O., Moraes, M. C. M. de, \& Evangelista, O. (2007). Política Educacional (4a ed.). Rio de Janeiro, RJ: Lamparina.

Silva, A. G. da. (1995). O Movimento Apaeano no Brasil: Um estudo documental (1954-1994). (Dissertação de Mestrado). Pontifícia Universidade Católica, São Paulo.

Soares, M. A. L. (1999). A educação do surdo no Brasil. Campinas, SP: Autores Associados/Bragança Paulista, SP: EDUSF.

\section{Sobre o Autores}

\section{José Geraldo Silveira Bueno}

Pontifícia Universidade Católica de São Paulo - PUC/SP

jotage@pucsp.br

https://orcid.org/0000-0002-8285-4135

Doutor em Educação, pela Pontifícia Universidade Católica de São Paulo (PUC-SP), Professor Titular do Programa de Estudos Pós-Graduados em Educação, História, Política, Sociedade da PUC-SP e líder do grupo de pesquisa "Processos de escolarização, desigualdades sociais e diversidades", cadastrado no CNPq. Áreas de interesse: política educacional, educação especial e processos de escolarização, desigualdades sociais

\section{Márcia de Souza Lehmkhul}

Fundação Catarinense de Educação Especial

lehmkuhlms@gmail.com

http://orcid.org/0000-0003-2405-2043

Doutora em Educação, pela Pontifícia Universidade Católica de São Paulo (PUC/SP), Pedagoga da Fundação Catarinense de Educação Especial. Áreas de interesse: política educacional, educação especial e formação de professores.

\section{Ricardo Schers de Goes}

Fundação Universidade Regional de Blumenau - FURB 
rsgoes@furb.br

http://orcid.org/0000-0001-5146-6765

Doutor em Educação pela Pontifícia Universidade Católica de São Paulo (PUC-SP), mestre em Psicologia pela Universidade de São Paulo (USP), mestre em Educação pela Pontifícia Universidade Católica de São Paulo (PUC-SP); Professor Universitário na Fundação Universidade Regional de Blumenau, Professor de Educação Infantil na rede pública da Prefeitura de Indaial/SC. Áreas de interesse: política educacional, educação especial, inclusão escolar e processos de escolarização.

\section{DOSSIÊ
Políticas Públicas em Educação Especial em Tempos de Ditadura arquivos analíticos de políticas educativas}

Volume 27 Número 62
3 de junho de 2019
ISSN 1068-2341

\section{(c)}

SORERIGHIS RESERVED O Copyright e retido pelo/a o autor/a (ou primeiro co-autor) que outorga o direito da primeira publicação à revista Arquivos Analíticos de Políticas Educativas. Más informação da licença de Creative Commons encontram-se em http://creativecommons.org/licenses/by-nc-nd/2.5. Qualquer outro uso deve ser aprovado em conjunto pelo/s autor/es e por AAPE/EPAA. AAPE/EPAA é publicada por Mary Lou Fulton Institute Teachers College da Arizona State University. Os textos publicados em AAPE são indexados por CIRC (Clasificación Integrada de Revistas Científicas, Espanha) DIALNET (Espanha),Directory of Open Access Journals, Education Full Text (H.W. Wilson), EBSCO Education Research Complete, ERIC, PubMed, QUALIS A1 (Brasil), Redalyc, SCImago Journal Rank; SCOPUS, SOCOLAR (China).

Curta a nossa comunidade EPAA's Facebook https://www.facebook.com/EPAAAAPE e Twitter feed@epaa_aape. 


\section{arquivos analíticos de políticas educativas conselho editorial}

Editor Consultor: Gustavo E. Fischman (Arizona State University)

Kaizo Iwakami Beltrao, (Brazilian School of Public and Private Management - EBAPE/FGV, Brazil), Geovana Mendonça Lunardi Mendes (Universidade do Estado de Santa Catarina), Gilberto José Miranda, (Universidade

Federal de Uberlândia, Brazil), Marcia Pletsch, Sandra Regina Sales (Universidade Federal Rural do Rio de Janeiro)

\section{Almerindo Afonso}

Universidade do Minho

Portugal

\section{Rosanna Maria Barros Sá}

Universidade do Algarve

Portugal

\section{Maria Helena Bonilla}

Universidade Federal da Bahia

Brasil

Rosa Maria Bueno Fischer

Universidade Federal do Rio Grande

do Sul, Brasil

\section{Alice Casimiro Lopes}

Universidade do Estado do Rio de

Janeiro, Brasil

\section{Suzana Feldens Schwertner}

Centro Universitário Univates

Brasil

\section{Flávia Miller Naethe Motta}

Universidade Federal Rural do Rio de Janeiro, Brasil
Alexandre Fernandez Vaz

Universidade Federal de Santa

Catarina, Brasil

\section{Regina Célia Linhares Hostins \\ Universidade do Vale do Itajaí, Brasil}

\section{Alfredo Macedo Gomes}

Universidade Federal de Pernambuco

Brasil

Jefferson Mainardes

Universidade Estadual de Ponta

Grossa, Brasil

Jader Janer Moreira Lopes

Universidade Federal Fluminense e

Universidade Federal de Juiz de Fora, Brasil

Debora Nunes

Universidade Federal do Rio Grande do Norte, Brasil

\section{Alda Junqueira Marin}

Pontifícia Universidade Católica de São Paulo, Brasil

\section{Dalila Andrade Oliveira}

Universidade Federal de Minas

Gerais, Brasil
José Augusto Pacheco

Universidade do Minho, Portugal

Jane Paiva

Universidade do Estado do Rio de

Janeiro, Brasil

Paulo Alberto Santos Vieira

Universidade do Estado de Mato

Grosso, Brasil

Fabiany de Cássia Tavares Silva

Universidade Federal do Mato

Grosso do Sul, Brasil

\section{António Teodoro}

Universidade Lusófona

Portugal

\section{Lílian do Valle}

Universidade do Estado do Rio de Janeiro, Brasil

\section{Alfredo Veiga-Neto}

Universidade Federal do Rio Grande do Sul, Brasil 


\section{archivos analíticos de políticas educativas consejo editorial}

Editor Consultor: Gustavo E. Fischman (Arizona State University)

Editores Asociados: Armando Alcántara Santuario (Universidad Nacional Autónoma de México), Angelica Buendia, (Metropolitan Autonomous University), Alejandra Falabella (Universidad Alberto Hurtado, Chile), Antonio Luzon, (Universidad de Granada), José Luis Ramírez, (Universidad de Sonora), Paula Razquin (Universidad de San Andrés), Maria Alejandra Tejada-Gómez (Pontificia Universidad Javeriana, Colombia)

Claudio Almonacid

Universidad Metropolitana de

Ciencias de la Educación, Chile

\section{Miguel Ángel Arias Ortega}

Universidad Autónoma de la

Ciudad de México

Xavier Besalú Costa

Universitat de Girona, España

Xavier Bonal Sarro Universidad

Autónoma de Barcelona, España

Antonio Bolívar Boitia

Universidad de Granada, España

José Joaquín Brunner Universidad Diego Portales, Chile

Damián Canales Sánchez

Instituto Nacional para la

Evaluación de la Educación, México

Gabriela de la Cruz Flores

Universidad Nacional Autónoma de México

Marco Antonio Delgado Fuentes

Universidad Iberoamericana, México

Inés Dussel, DIE-CINVESTAV, México

Pedro Flores Crespo Universidad Iberoamericana, México
Ana María García de Fanelli

Centro de Estudios de Estado y

Sociedad (CEDES) CONICET,

Argentina

Juan Carlos González Faraco

Universidad de Huelva, España

María Clemente Linuesa

Universidad de Salamanca, España

Jaume Martínez Bonafé

Universitat de València, España

\section{Alejandro Márquez Jiménez}

Instituto de Investigaciones sobre la Universidad y la Educación, UNAM, México

María Guadalupe Olivier Tellez, Universidad Pedagógica Nacional, México

Miguel Pereyra Universidad de

Granada, España

Mónica Pini Universidad Nacional de San Martín, Argentina

Omar Orlando Pulido Chaves

Instituto para la Investigación

Educativa y el Desarrollo Pedagógico (IDEP)

José Ignacio Rivas Flores

Universidad de Málaga, España
Miriam Rodríguez Vargas

Universidad Autónoma de

Tamaulipas, México

José Gregorio Rodríguez

Universidad Nacional de Colombia, Colombia

Mario Rueda Beltrán Instituto de Investigaciones sobre la Universidad y la Educación, UNAM, México José Luis San Fabián Maroto Universidad de Oviedo, España

Jurjo Torres Santomé, Universidad de la Coruña, España

Yengny Marisol Silva Laya Universidad Iberoamericana, México

Ernesto Treviño Ronzón

Universidad Veracruzana, México

Ernesto Treviño Villarreal

Universidad Diego Portales Santiago, Chile

Antoni Verger Planells Universidad Autónoma de Barcelona, España

Catalina Wainerman

Universidad de San Andrés, Argentina

Juan Carlos Yáñez Velazco

Universidad de Colima, México 


\section{education policy analysis archives editorial board \\ Lead Editor: Audrey Amrein-Beardsley (Arizona State University) \\ Editor Consultor: Gustavo E. Fischman (Arizona State University) \\ Associate Editors: David Carlson, Lauren Harris, Eugene Judson, Mirka Koro-Ljungberg, Scott Marley, Molly Ott, Iveta Silova (Arizona State University)}

Cristina Alfaro

San Diego State University

Gary Anderson

New York University

Michael W. Apple

University of Wisconsin, Madison

Jeff Bale

University of Toronto, Canada

Aaron Bevanot SUNY Albany

David C. Berliner

Arizona State University

Henry Braun Boston College

Casey Cobb

University of Connecticut

Arnold Danzig

San Jose State University

Linda Darling-Hammond

Stanford University

Elizabeth H. DeBray

University of Georgia

David E. DeMatthews

University of Texas at Austin

Chad d'Entremont Rennie Center

for Education Research \& Policy

John Diamond

University of Wisconsin, Madison

Matthew Di Carlo

Albert Shanker Institute

Sherman Dorn

Arizona State University

Michael J. Dumas

University of California, Berkeley

Kathy Escamilla

University ofColorado, Boulder

Yariv Feniger Ben-Gurion

University of the Negev

Melissa Lynn Freeman

Adams State College

Rachael Gabriel

University of Connecticut
Amy Garrett Dikkers University

of North Carolina, Wilmington

Gene V Glass

Arizona State University

Ronald Glass University of

California, Santa Cruz

Jacob P. K. Gross

University of Louisville

Eric M. Haas WestEd

Julian Vasquez Heilig California

State University, Sacramento

Kimberly Kappler Hewitt University

of North Carolina Greensboro

Aimee Howley Ohio University

Steve Klees University of Maryland

Jaekyung Lee SUNY Buffalo

Jessica Nina Lester

Indiana University

Amanda E. Lewis University of

Illinois, Chicago

Chad R. Lochmiller Indiana

University

Christopher Lubienski Indiana

University

Sarah Lubienski Indiana University

William J. Mathis

University of Colorado, Boulder

Michele S. Moses

University of Colorado, Boulder

Julianne Moss

Deakin University, Australia

Sharon Nichols

University of Texas, San Antonio

Eric Parsons

University of Missouri-Columbia

Amanda U. Potterton

University of Kentucky

Susan L. Robertson

Bristol University
Gloria M. Rodriguez

University of California, Davis

R. Anthony Rolle

University of Houston

A. G. Rud

Washington State University

Patricia Sánchez University of

University of Texas, San Antonio

Janelle Scott University of

California, Berkeley

Jack Schneider University of

Massachusetts Lowell

Noah Sobe Loyola University

Nelly P. Stromquist

University of Maryland

Benjamin Superfine

University of Illinois, Chicago

Adai Tefera

Virginia Commonwealth University

A. Chris Torres

Michigan State University

Tina Trujillo

University of California, Berkeley

Federico R. Waitoller

University of Illinois, Chicago

Larisa Warhol

University of Connecticut

John Weathers University of

Colorado, Colorado Springs

Kevin Welner

University of Colorado, Boulder

Terrence G. Wiley

Center for Applied Linguistics

John Willinsky Stanford University

Jennifer R. Wolgemuth

University of South Florida

Kyo Yamashiro

Claremont Graduate University

Miri Yemeni

Tel Aviv University 